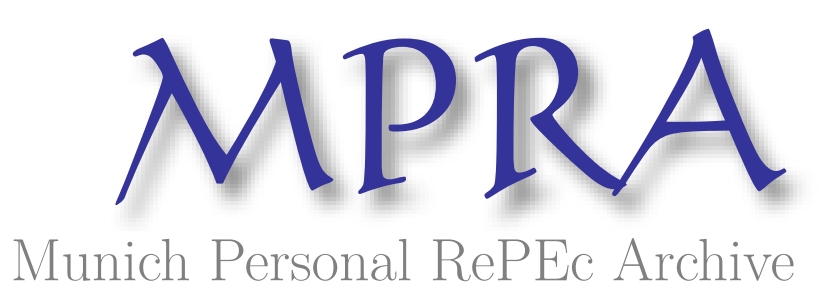

\title{
The Political Economy of Globalization - Revisiting Stephen Hymer 50 Years On
}

Dunning, John and Pitelis, Christos

13 November 2009

Online at https://mpra.ub.uni-muenchen.de/23184/

MPRA Paper No. 23184, posted 10 Jun 2010 05:47 UTC 


\title{
The Political Economy of Globalization - Revisiting Stephen Hymer 50 Years On*
}

\author{
John H Dunning \\ Professor Emeritus, University of Reading and Rutgers University
}

Christos N Pitelis

Director, Centre of International Business and Management (CIBAM)

Judge Business School, University of Cambridge

\footnotetext{
${ }^{*}$ We are grateful to Jean Boddewyn, John Cantwell, Lorraine Eden, Neil Kay, Alan Rugman, Roger Sugden and
} Mo Yamin for comments on earlier drafts. The usual disclaimer applies. 


\section{$\underline{\text { Abstract }}$}

We discuss issues pertaining to the political economy of "globalization", in the context of the seminal contribution by Stephen Hymer. While Hymer's contribution to the theory of the multinational enterprise (MNE) and foreign direct investment (FDI) is widely recognized, his contribution to the political economy of what he called "multinational corporate capital" has received less attention. In this paper we revisit some of the issues he raised, notably uneven development, global governance and central planning in the context of post-Hymer scholarly thinking and the shifting global landscape. In so doing we also speculate on the challenges and future of globalization.

Keywords: Stephen Hymer, International Political Economy, Institutions, Globalization, Sustainability. 


\section{$\underline{\text { I. Introduction and Overview }}$}

Our aim in this paper is to reassess issues pertaining to the "political economy of globalization" in the context of revisiting the contribution of Stephen Hymer on the occasion of 50 years since the writing of his now classic doctoral thesis. Hymer, who was born in 1934, and died in a car accident forty years later, in 1974, has made a seminal and lasting contribution to the theory of the MNE and FDI, and to International Political Economy (IPE). He was one of the first economists to explore the nature and determinants of the internationalization of production ('globalization') and its relationship to international development, MNE-host country relationships and global governance. Hymer first articulated his views 50 years ago, in his doctoral thesis (completed in 1960), and later, in around forty articles in economics and political economy journals. Among these, a 1968 article written in French and two 1970 articles, one in the American Economic Review (1970A) and the other in a book edited by Bhagwati (1970B), proved to be most influential.

In his 1960 thesis (eventually published by MIT Press in 1976), Hymer criticised extant theory of foreign portfolio investment, not only for its inability to explain some 'stylised facts' of FDI, but, more importantly, for its failure to explicate how the power, strategies and governance of firms might influence their decision to cross national boundaries. He distinguished between different modalities by which firms might extend their territorial ambit, e.g., by licensing, tacit collusion, joint ventures and FDI, and he tackled the question as to why a firm would choose to own and/or control productive activities in a foreign country, despite the obvious costs of so doing, e.g. those to do with language, cultural and other barriers of venturing into unfamiliar locations. Hymer was the first economist to address the question 'Why MNEs?' and 'Why FDI?' vis-à-vis alternative forms of foreign operations. In his thesis, Hymer suggested two major reasons and one minor for FDI. The two major ones were the 'removal of conflict' between firms in different countries and the profitability of 
exploiting firm specific advantages from a foreign location. The benefit of diversification was the minor one- minor, because diversification did not necessarily involve the control of overseas assets. ${ }^{1}$

Already in his thesis, Hymer attributed FDI to market imperfections, mainly of the structural type, (Dunning and Rugman 1985). However, he did explicitly mention that in choosing to own foreign value added activities, a firm 'substitutes', 'internalises' or ‘supersedes’ cross-border markets (Dunning and Pitelis 2008).

In his 1968 article, Hymer further developed this line of thought. He explicitly acknowledged, and built on, Ronald Coase's classic article (Coase 1937) - by attributing the superiority of firms over markets to high market transaction costs. In his 1970a AER paper, Hymer dealt with the 'efficiency/contradictions' of MNEs. He saw the two terms as synonymous, in so far as he perceived the efficiency of MNEs to be that directly related to oligopolistic decision-making. In this article, Hymer drew on Alfred Chandler's work (Chandler 1962) in proposing a 'law of increasing firm size', and went on to assert that one result of this law was that "bigness is in part paid by fewness and a decline in competition" (p. 54). As a consequence, he recommended that international anti-trust institutions and policies should be strengthened, and the protection - indeed encouragement - of local 'infant entrepreneurs' (p. 55). ${ }^{2}$

In his 1970a article, Hymer recapitulated some of his earlier ideas on the MNE and FDI, and went on to complement his 'law of increasing firm size' with that of 'uneven development'. He also applied 'location theory' to the Chandlerian analysis of the evolution of the firm. In doing so, he examined the relationship between the 'microcosm' and the 'macrocosm' of MNE activity. This led him to articulate a 'correspondence principle', which attempted to identify and relate the centralisation of control within corporations to the concentration of economic activity within the international economy. 
For Hymer, the need of MNEs both to access new markets and natural resources products would lead them to consider investing in less developed countries (LDCs). While he acknowledged this would frequently benefit the recipient economies, he argued that, more often than not, it resulted in a dependent and uneven development. In cases where the increasing power of MNEs was likely to erode that of host countries, it would do so asymmetrically; less so for 'strong' than for 'weak' states. The emasculation of the power and authority of national governments would create a situation in which MNEs would need to mobilise new sources of authority to fill the vacuum created. This, in time, according to Hymer, would bring about the emergence of a variety of supranational organizations, help create an international capital market, further the spread of international production, and, in due course, lead to a system of global governance. The perceived distortions and the inequities of any 'global monopoly', led Hymer to conclude that a socialist economic system of the central planning type was preferable to that of market forces as a way to organise the creation and distribution of wealth.

Taken as a whole, Hymer's contribution predated much of the extant theory of the MNE, such as the transaction-costs-internalisation analysis of Buckley and Casson (1976), Rugman (1981) and Hennart (1982), and the eclectic paradigm of Dunning (1977) ${ }^{3}$, and recent concerns with 'globalisation'. Hymer even predicted a move towards the current externalisation (outsourcing) of the cross-border activities of MNEs.

Hymer's views of the MNE and FDI have been widely acknowledged and celebrated. He is considered to be the father-figure of the field of International Business (IB) and many papers and special issues or journals have been written on his work and contribution, see for example Contributions to Political Economy (2002), International Business Review (2006), Dunning and Pitelis (2008). However, little has been done on Hymer's contribution to Political Economy. We try to rectify this here, while simultaneously celebrating the 50th year 
anniversary of Hymer's doctoral thesis.

In terms of method and structure, we derive and present Hymer's analytical framework in the context of his era in Section II. We then consider the evolution of Hymer's analytical framework, and the predictions and prescriptions he drew from it in Section III. In section IV, we assess Hymer's scholarly contribution, in terms of its consistency with his own analytical framework, and the shifting global landscape and scholarly thinking, and extend his framework and revisit his predictions and prescriptions. Finally, in the last Section (V) we speculate on the future of globalisation as seen through the lens of this new perspective and provide concluding remarks.

\section{Hymer's era and framework}

\section{Hymer's era}

Hymer lived in an era in which inter-firm competition was predominantly based on the economies of large size, and was conducted between oligopolists. At the time, production of most goods and services was concentrated in planned economies or undertaken by large private hierarchies in market economies. There was little sign, in the late 1960s and early 1970s, of the ability (or, indeed, the willingness) of any developing country to 'take-off' or pursue an independent development path. To Hymer, even his own homeland, Canada, looked more like a colony than a nation. He felt like an 'alien' in a country whose economy was largely controlled by large foreign-owned (and especially US) businesses. As he saw it, the primary objective of MNEs was to protect or enhance the monopolistic advantages which they had developed in their home markets, through territorial expansion (Cohen et al, 1979).

Hymer's time was also one in which the tenets and methodologies of neoclassical economics dominated, yet at the same time, the concept of "homo economicus" and of the goals and means of development were being increasingly challenged, particularly by 
'Marxist' scholars (Dunning, 2006). Hymer himself made his 'cathartic' commitment to Marxism in 1967. Earlier, he had received a formal training in mainstream economic theory, and was widely acknowledged by those who knew him to have a superior analytical mind (Kindleberger, 1984). In his 1968 paper, he embraced Coasean transaction cost analysis and Bain-type industrial organization (IO) theory as extant, and set himself the task of applying these concepts to explain the determinants of international direct investment. ${ }^{4}$ Critical elements of the IO perspective were, first, its comparative static nature, second, its assumption of perfect knowledge $e^{5}$ and a given state of technology, and third, its treatment of inter-firm cooperation primarily as a means of engaging in price collusion.

In this context, Hymer's adoption of the concept of global collusive oligopoly would appear to be a natural outcome of his background, and to be consistent with related scholarly thinking of the time. Hymer's 1960 'neoclassical' thesis for example is a close precursor of Baran and Sweezy's (1966) subsequent Marxist analysis. This framework focuses almost exclusively on (surplus) 'value capture' through the exploitation of monopoly power, and downplays the role of 'value creation' through the efficient allocation by resources and capabilities. For Charles Kindleberger (writing in 1984 and 2002) there had been little scholarly advance on our understanding and the causes of FDI since Hymer. While we would assert that Hymer's scholarship predates the later ideas on FDI and the MNE, we also believe that its near exclusive focus on monopoly led him astray on his analysis of prescription and prediction on some issues. To substantiate our claims, we start with Hymer's analytical framework.

\section{Hymer's Framework.}

The extant theory of the firm at the time of the writing of Hymer's thesis was the neoclassical market structure-based approach, as set out by Bain (1956). The idea that incumbent oligopolists behave collusively was central in Bain's work and gave rise to Hymer's first major reason for FDI - viz the reduction of rivalry. When firms are 
interconnected, he wrote, "they compete in selling in the same market or one of the firms may sell to the other" and because of this "it may be profitable to substitute centralised decision making for decentralised decision making" (Hymer 1976 p37). In the case of horizontal competition be it between firms within a country or across national borders, he observed that "some form of collusion may be profitable. One form of collusion is merger" (p. 38)

Hymer drew support for the reduction of rivalry thesis from the description by Dunning (1958) of the international 'tobacco case' (p. 89). Hymer fully cited Dunning's description, that "at the turn of the century, the British tobacco industry was literally "invaded" by American capital. Restricted in its sales by a high tariff wall imposed on U.S. cigarettes, the American Tobacco Company acquired the young and prosperous firm of Ogden's, Ltd., in September 1901, and straight away launched an extensive publicity campaign to sell cheap cigarettes. The Chairman of the U.S. company at that time made no secret of his intentions, viz.: "to obtain a large share of the tobacco trade both of England and the Continent," and he threatened to spend up to $£ 6$ million in doing just this. The reaction of the British producers was prompt for within a month of the purchase of Ogden's, thirteen of the leading tobacco companies had amalgamated and formed themselves into Imperial Tobacco Company, with an issued capital of $£ 14 \frac{1}{2} 2$ million. Then followed several months of cut throat competition between the two concerns. Eventually, a market sharing agreement was reached in September 1902; Ogden's became part of the Imperial Tobacco group, which was given the monopoly of the British and Irish markets, whilst the United States and its dependencies were to be supplied by the American Tobacco Company. A new concern, the British -American Tobacco Co., Ltd., was set up to handle the remainder of the export business and was allocated factories both in the United States and in the United Kingdom" Dunning (p. 30 - 31), emphasis added. 
The part of this extract referring to cutthroat competition which eventually led to market sharing was to be used almost verbatim by Hymer in most of his major subsequent works (Hymer, 1968, 1970, 1970A). It was subsequently extended in his joint publications with Rowthorn (Hymer and Rowthorn, 1970) and later received formal support by Graham (1990) and by Rowthorn (1993). ${ }^{6}$

While the reduction or rivalry thesis was an extension of received IO theory, the 'advantages' thesis was largely Hymer's own conception and may be reasonably argued to be the forerunner of internalization theory (see Dunning and Pitelis, 2008). Based on such insights, Hymer was able to make his fascinating predictions, extrapolations and prescriptions that we aim to revisit here.

From an epistemological point of view, there are several important questions that can be usefully addressed. These are (i) how Hymer's conceptual framework is linked to his predictions, extrapolations and prescriptions; (ii) to what extent do the shortcomings of his framework help explain some of his most problematic predictions and prescriptions; and (iii) whether, and how, an improved analytical framework might allow a set of predictions that may have been made in Hymer's time, but which are more in line with subsequent developments in the global landscape. We shall deal with each of these questions in turn.

\section{Hymer's Evolving Ideas}

In his thesis and his 1968 paper, Hymer integrated IO with Coase's internalization theory and extended both to explain the inter-national expansion of the firm, see Casson (1990), Dunning and Pitelis (2008). In addition, in 1968 Hymer also drew on Chandler's (1962) Strategy and Structure, and another classic book, Monopoly Capital -this time in the 
Marxist tradition-by Baran and Sweezy (1966). Coase, Chandler, and Baran and Sweezy were important for Hymer's evolving analytical framework.

Hymer's two other major papers were contemporaneous (Hymer cited his paper in Bhagwati (1970B) in his AER paper in the same year (Hymer, 1970A)). In both papers, the major influences of his thinking were Coase (1937), Chandler (1962), Chandler and Redlich (1961), and a joint work by Hymer with Stephen Resnick, Hymer and Resnick (1969/70) on international trade and 'uneven development'. In the AER paper Hymer's focus on markets and firms is directed at their implications for the international division of labour, one type being coordinated by markets, the other by entrepreneurs. Hymer then built on Chandler (1962) and Chandler and Redlich (1961) to examine the evolution of the large corporation from its Marshallian beginnings to the multidivisional, the conglomerate and the MNE. He pointed to three levels of decisions within firms. The lowest (third) level concerns the governance over day-to-day operations; level two is responsible for coordinating managerial decisions throughout the enterprise; and level one is responsible for 'good determination and planning' or 'strategy not tactics' (ibid p.52).

In the $A E R$ paper Hymer also attempted to develop his ideas in four new directions: first, the issue of oligopoly and dynamic (or inter-temporal) efficiency, second, on the focus of decision-making, third, on the relationship between large firms and (small) countries, and fourth, on the idea of 'supra-nationality' (global governance). We briefly deal with each of these directions.

In neoclassical IO theory perfect competition and perfect contestability are necessary conditions for static (Pareto) efficiency. However, they also remove any inducements to innovate, as they result in zero monopoly profits. This observation was originally made by Schumpeter (1942), and was later extended by Baumol (1991) for the case of contestable markets. If innovation is seen as a determinant of long-term growth, it follows that some sort 
of imperfect market structure could be better for dynamic efficiency. Schumpeter's concept of creative destruction could be viewed as a means of effecting long-term (inter-temporal) efficiency through big business competition. In this sense, while oligopoly is a form of static inefficiency, it may well be a source of dynamic, inter-temporal efficiency (Penrose 1959).

Hymer's attempt to critique Schumpeter was in terms of his questioning the direction of technological change induced by oligopolies. In particular, Hymer suggested that oligopolies will aim to create a demand for their products through an international 'trickledown' or 'demonstration' effect, first by introducing them to the developed countries, and then to other countries. The orchestration of the process by few corporations interested in their own profit made it unlikely that they would make optimal use of extant scientific and technological developments (Hymer 1970A,B).

On the international hierarchy of decision making, Hymer predated the contemporary global integration versus local responsiveness debate, see Barlett and Ghoshal (1989). In his AER paper, he observed that the governance of MNEs was torn in two directions. On the one hand, they needed to adapt to local circumstances in each country. This called for decentralized decision-making. On the other hand, it was in their interests to co-ordinate their activities in various parts of the world and stimulate the flow of the ideas and managerial capabilities from one part of their empire to another. This called for more centralized controls. In Hymer's words MNEs “must develop an organizational structure that balances the need to co-ordinate and integrate operations with the need to adapt to a patchwork quilt of languages, laws, and customs (ibid p.58).

As regards the relationship between large investing firms and small host countries, Hymer observed their different objectives, the former being primarily interested in maintaining the net surplus from their operations, of the foreign subsidiaries and the latter in the net benefits created by them. He argued that as the corporations usually had more 
bargaining power, it might be possible for them to pursue their interest at the expense of the desired development of the small developing countries, and this would lead to a state of 'underdevelopment'. However, Hymer went on to argue that, such extreme cases are no longer possible because of the increased political strength of the local middle class in most underdeveloped countries and because of the changed nature of foreign investment. He observed that modern MNEs were interested in manufacturing in developing countries as well as accessing raw materials; they, therefore, want a growing market for advanced products and an educated, urbanized labour force. They were no longer tied to traditional backward governments, rather choosing to have a stake in an active government sector that promotes growth and provides education and infrastructure. The "new foreign investment" is, then, a far cry from the "banana republic" (p.61). However Hymer believed that the emergent development retains 'an uneven quality, and all the inefficiency that that implies, albeit in a more advanced and progressive form than characterized the enclave economies of the previous round of foreign investment' (ibid p.62)

The erosion of state power leads Hymer to ask the question: 'who is going to perform the government's functions?' (p.62) He continues that 'multinational agencies will need to be developed to maintain full employment and price stability. Yet such organizations do not exist at present, nor can they be built quickly' (p.61).

Hymer concluded his $A E R$ paper by prescribing central planning as the most suitable macro economic institution to set the rules for wealth creation. He felt that the large corporation illustrates how real and important are the advantages of large-scale planning, but it does not tell us how best to achieve wider domains of conscious co-ordination. Broadly speaking, there are two main alternatives. Either MNEs integrate one value added activity over many countries or states should integrate many industries over one country. According to Hymer, the advantage of the second option is that it keeps the economy within the boundary 
of the polity and the society. It thus causes less tension and creates the possibility of bringing economic power under control by removing the wastes of oligopolistic anarchy' (Hymer, 1970, p.63).

Hymer's other 1970 paper, (Hymer 1970B) in Bhagwati revisits and further pursues these ideas. In this contribution, Hymer looks towards the year 2000. In doing so, he formulates two economic laws: viz the Law of Increasing Firm Size and the Law of 'Uneven Development'. Here, besides being influenced by the scholarly writings of Coase and Chandler, Hymer draws extensively on those of Karl Marx. He also addresses issues raised earlier by Alfred Marshall, Joseph Schumpeter, Adam Smith, Karl Polanyi, Ray Vernon and Chester Barnard.

In Part I of this paper, Hymer, first reiterates and expands on his earlier 1968/1970A ideas on the evolution of large firms. In particular, he attempts to extrapolate the trends in business enterprise (the 'microcosm'), on the macro-economic environment (the 'macrocosm'). He claims that a regime of North Atlantic MNEs would tend to produce a hierarchical division of labour between geographical regions which corresponded to a vertical division of labour within the firm. It would tend to centralize high-level decision-making occupations in a few key cities in the industrialized countries: these would be surrounded by a number of regional sub-capitals, while the rest of the world would comprise a multitude of smaller towns and villages. Income, status, authority, and consumption patterns would radiate from the cities along a declining curve, with the result that any existing pattern of income inequalities and dependency would be perpetuated.

For Hymer the application of 'location theory to the Chandler- Redlich scheme suggests a correspondence principle, which relates centralization of control within the corporation to centralization of control within the international economy'. Applying this idea to the world economy, he predicts the creation of 'core' cities and economies, and a 
'hinterland', with the growth in the hinterland resulting in growth in the core, but not vice versa.'. He further suggests that a two stage 'trickle-down', and demonstration effect will tend to reinforce 'patterns of authority and control'. This process, according to Hymer, is likely to 'reduce options for development, and erode the power of the nation states, but asymmetrically - more so for small than for large countries, as in his words "Government - in the metropolis can,.... capture some of the surplus generated by the multinational corporations and use it to further improve their infrastructure and growth" (Hymer, 1970A, p.128).

In Part III, Hymer discusses political economy issues, including the potential role of labour, the middle classes, excluded groups, and the 'socialist bloc'. He concludes that, despite any advantages it may possess the multinational "creates hierarchy rather than equality, and it spreads its benefits unequally" Hymer 1970A (p.133). He moves on to

prescribe 'a system of regional planning' or 'a socialist solution' (p. 135). He expresses some optimism for this to happen. Again, in his words, although "power at the centre is great ... ...the forces for positive change are much stronger and the centre seems to be losing its will and self-confidence" (ibid p.135).

\section{Hymer's framework, predictions and prescription in relation to subsequent}

\section{developments}

\section{Framework, Predictions and Prescription}

Hymer's analytical framework involved a focus on the superior profitability which he perceived internalisation would confer on firms: first from their ownership of, or access to, particular assets, competences, co-ordinating abilities; and second, from an increase in market power through the reduction of competition. Hymer treated these two benefits arising from control as being the same. He claimed that 'the control of the foreign enterprise is desired in 
order to remove competition between that foreign enterprise and enterprises in other countries. Or the control is desired in order to appropriate fully the returns on certain skills and abilities' (Hymer, 1976: 25). This treatment is questionable. While any reduction of rivalry or inter-firm collusion are practices almost exclusively concerned with power-control, rather than with efficiency enhancement, capturing value out of one's various advantages, can help engender efficiency and value creation (Dunning and Pitelis, 2008).

Hymer eschewed from the question of whether advantages can be used efficiently. He tried to tackle the question of inter-temporal efficiency and market structure by focusing on the 'direction of change' and its uneven characteristics. Importantly, Hymer failed to deal with the relationship between the static and dynamic efficiency of firms. Nor did he seek to identify the origin or creation of the 'advantages', and their relationship not just to value appropriation/capture, but also to efficiency as well as the link between value capture and efficiency. In addition Hymer claimed that the direction of innovation by MNEs was not necessarily in line with consumers' needs, and that any spill-over effects were unevenly distributed between developed and developing nations. Both these arguments are contestable. The first involves the difficult issue of defining what the needs of the people are. The second assumes that an alternative system would have better properties - an issue to which we shall later return.

A final, yet crucial, aspect of Hymer's perspective concerns the process of integration itself. This in Hymer is exclusively seen as a strategy for profitability through market power. This argument has two limitations. First, once it is acknowledged, that integration may help reduce market transaction costs, its value-creating- efficiency element has also to be part of the picture. This becomes even more the case when one incorporates some of the other efficiency advantages discussed by Hymer (1968, 1970A,B), such as the speed of intra-firm 
knowledge transfer and the learning advantages which the internationalization of production helps facilitate.

To summarise, for Hymer, the advantages of integration in terms of value capture through monopoly power effected through the reduction in production and transaction costs, provided the raison d'être _for FDI and MNE activity. On this basis Hymer predicted. First, a continued increase in firm size through growth, whether it be accomplished by internalisation or externalisation (the 'law' of increasing firm size) and the interpenetration of cross-border investments, market-sharing and global collusive oligopoly. Second, unevenness of development between developed and developing countries which results from extrapolating the microcosm of the MNE to the macrocosm of international political economy (his 'law' of uneven development). Third, the need for 'supra-nationality' and global governance, in order to address the failures of the MNEs and nation states to provide global governance. On this basis, Hymer prescribed central planning: the vertical integration of industries within nations by national governments, instead of integration of the same industries by private MNEs across nations (Hymer 1970A,B).

Hymer's first prediction has been extensively discussed on the IB literature (see for example Dunning and Pitelis, 2008). Here our focus is on his predictions on uneven development, central planning and global governance. First, we critically assess Hymer's predictions and prescriptions on the basis of their consistency with his own analytical ideas and arguments. Then we repeat this exercise in the context of our contemporary global landscape and that of scholarly thinking. Following this, we aim to build on the work of Hymer and subsequent scholars, by suggesting a framework that overcomes the limitations of Hymer's model, and speculate a little on how he might have revisited his ideas with the benefit of that framework. Finally, we venture into some predictions and prescriptions of our own about the future of global capitalism. 
Starting from,Hymer's 'law of uneven development', this is in line with his belief that firm specific asset- based advantages and competences primarily originate in developed countries, and then 'trickle down' to developing ones. This leads to his opinion of an asymmetrical erosion of the power of the developing countries. In this context, the idea of the emergence of a 'pyramid' of decision making and the possibility of a 'core' and a 'hinterland' follow almost naturally from his assumptions and his prediction that this will lead to an uneven division of the benefits of growth in favour of developed countries.

Hymer's idea of 'uneven development' flies in the face of traditional neoclassical growth theory, Solow (1956), and/or the 'Washington consensus' - based arguments, Dunning $(2003 ; 2006)$. These theories and arguments predict convergence is likely to follow from trade liberalization, with developing countries having more scope for further improvement-catching up (Sala-i-Martin, 2006). It is also not backed up by 'development of underdevelopment'- type arguments, which suggest that MNEs can create or help sustain the underdevelopment of countries (Eden and Lenway, 2001).Finally, parts of the contemporary outward FDI from developing countries is of an asset augmenting kind and directed to developed countries. Rightly or wrongly, many developing countries believe this is one of the ways - and certainly the speediest - to reduce the technological gap between them and the richer industrial nations.

Despite its 'middle ground' position, the uneven development thesis only follows under Hymer's specific assumptions, particularly concerning the role of the state, (its nature, motivations, interests and constraints) in developing countries, as well as its willingness and/or ability to devise and implement policies that lead to catch-up.Accordingly the predictive power of his thesis depends crucially on these underlying assumptions and frameworks. 
Hymer's prediction on the need for international organisations, and for some kind of global governance to regulate the operations of MNEs follows from his observation that such firms and the erosion of the power of nation states leave a vacuum which needs to be filled. It has also proven prophetic. Following his work, organisations such as the World Trade Organisation (WTO) have emerged which today play an important role influencing the rules of the game in international trade. A major lacuna in Hymer's analysis, however, concerns the question of the purpose of this emergence. Hymer does not articulate a theory of the nation state and its competition and regulation politics vis-à-vis MNEs. In the absence of a theory of the state, competition, industrial and regulation policies, it is difficult to identify exactly the contents of the vacuum which 'supra-nationality' is expected to fill.

Hymer's prescription for 'central planning' may also follow from his analysis, if we assume that any efficiency advantages of private MNEs will continue to be generated even in their absence. In this case it would make sense to replace the advantages of size (and eliminate its downsides), by integrating industries within nations. Of course, we would also need to assume the absence of government failure - a rather heroic assumption (Chang 1994).

\section{Post-Hymer Developments in relation to his ideas}

In respect of the theory of the MNE and FDI, the major development in the 1970s and 1980s was more intensive examination of the 'transaction costs' approach, and the introduction of envelope of internalization (I), ownership (O) 'location (L) as set out by Dunning $^{7}$. As we have already established, it is now accepted that Hymer was the father figure of the internalisation approach to understanding the modality of international business activities. In contrast to Hymer, however, transaction costs and the OLI focus on the efficiency impact of the advantages. The value creation component of FDI and MNE activity 
was also strengthened by the other major scholarly developments on the theory of FDI and the MNE in the 1990s, viz the resource-based and evolutionary theories, for example Teece (1977), Kogut and Zander (1993). Such theories draw on the resource-based view (RBV) of strategic management (see Mahoney, 2005, for an extensive coverage).

How exactly might we best incorporate an efficiency- value creation element into Hymer's framework of thinking? One way to approach this issue might be to revisit Hymer's predictions, extrapolation and prescription, from a knowledge-learning-based lens and then compare how these might help explain the post-Hymer's shifting global landscape. We may then also dare to speculate a little on the future of global capitalism using this revised framework.

Starting with Hymer's predictions, a value creation cum value capture perspective is consistent with the "law of increasing firm size" indeed it adds credence to it. For example Penrose (1959) has cogently argued that a firm's ability to access or learn from new knowledge will tend to remove any constraints to growth, including those which arise from any deficiency of managerial services and the difficulties for authoritative communication and coordination. These limits will tend to recede as firms learn and act to ameliorate them. In this sense, while there are limits to growth, they do not arise from size per-se as predicted by Hymer. The main contribution of the combined value creation/ value capture perspective is that it argues that growth may be the result of improved efficiency, innovation and learning as much as by increasing market power. ${ }^{8}$

Through efficiency and/or an extension of their market and political power, and by organic growth or acquisitions, the last 50 years has seen a continuous growth in the world's largest firms. This gives credence to Hymer's first law (Dunning and Pitelis, 2008). Thus the incorporation of the efficiency and value creation into Hymer's model, adds more support to his first "law". The recent dynamic growth of outsourcing (UNCTAD, 2003; Teece, 2006), 
alongside continued growth of firm size moreover, is testimony to the strength of Hymer's analytical framework and his superior insight.

On the other hand, Hymer's predictions with respect to global collusive oligopoly have been less successful. While sectors and companies, as diverse as beverages, commercial aircraft (Boeing-Airbus) and IT appear to be in line with Hymer's predictions, in others there is, intensifying competition through innovation, new entrants, trade liberalization, improvement in information and communication technologies (ICT), and reduced transportation costs. Interestingly, it is often through the very presence of large players that new competitors emerge. The emergence of Chinese competitors to US electronic and computer firms have come from the international strategy of such firms: Lenovo, after its acquisition of the PC division of IBM, is set to become a major global player. Outsourcing has helped create major Indian IT players, who now compete head-on with the leading MNEs from the developed countries (Teece, 2006). In short, we would claim that Hymer failed to appreciate the importance of new competition (Best 1990) through innovation, the emergence and role of small firms and the role of government in developed and developing countries. While firms keep growing, the scope for "global collusive oligopoly" in major, especially 'high - tech' sectors seems to be far off. This is particularly the case in a changing global landscape, in which the very boundaries of firms and sectors become fused and fuzzy and non-collusive forms of inter-firm cooperation abound (Richardson 1972).

Concerning Hymer's prediction of the growth of 'supranational' entities. Post-Hymer international organizations such as the WTO have emerged, the role of the World Bank of the IMF has become more high profile; regional blocks, such as the EU have widened and deepened their integration and new blocks (e.g. NAFTA and ASEAW) have appeared. It is, however, less clear whether 'supra-nationality' has emerged for the reasons advanced by Hymer. For Hymer "supra-nationality" was needed to fill the vacuum created by the 
asymmetric erosion of state power. However, he offered little specific guidance of the nature and role of such organizations. For example his "imperialism thesis" (Cohen et al, 1979) would suggest he thought that international organizations would lead to an increased concentration of economic power. Certainly the World Bank and the IMF have subsequently been criticized along these lines (e.g. Stiglitz 2002). Moreover Hymer correctly predicted the growth of "supra-nationality", but he failed to either integrate it fully into his value capture framework or explore its complexities, nature and contradictions. In short, Hymer's "supranationality" thesis is neither fully in line with his own analytical framework, nor adequately developed. This remains a critical area for further research (Boddewyn and Brewer, 1994).

The above considerations are also relevant to any assessment of Hymer's prediction of dependent and "uneven development". The events of the last 35 or more years seem to have been rather unkind to Hymer here. While it is true that large areas in the globe, notably Africa, have remained underdeveloped, there have also been spectacular successes, notably in Asia, and in Central and Eastern Europe, at least before the recent crisis. In the early 2000s, for example, India and China are experiencing dramatic growth; and are doing so by applying a wide array of policies and development models often favourable both to inbound and outbound FDI. While these countries initially exhibited significant state intervention (Chang, 2002), India's most recent development; e.g. the growth of the IT sector in Bangalore seems to have taken place without such intervention (Hill, 2009). The take-off of Central and Eastern European firms has been linked, among others, to "near-shoring” by MNEs and remittances form their migrants. More generally a new paradigm of development seems to be emerging (Dunning, 2006).

Hymer's exclusive focus on value capture also led him to underplay the significance of learning by developing countries, competitors and the introduction of pro-development government policies. Post-Hymer's development has been uneven, but often in favour of 
developing countries. This possibility was not considered by Hymer, because of his emphasis on the power of large firms to protect "their" technologies and competitive advantages, outcompete their rivals, and weaken the power of developing countries. While large firms do try and achieve these objectives, some nation states are very strong, new MNE competitors from developing countries do emerge, competitors from developing countries do manage to access, absorb and upgrade technology Ramamurti (2004). In all, there exists a very complex dynamic system, which is simply not explicable in terms of large firms controlling everything all the time. While post-Hymer "uneven development" in favour of those already better off, has taken place (Driffield and Love, 2005), on balance, "uneven development" seems to have favoured some emerging countries.

Our discussion of the last two points also weakens the force of Hymer's belief in the merits of 'central planning'. Even with global collusive oligopoly and uneven development, the case for central planning as a macro-institutional system should be at least partly based on its relative efficiency properties - which Hymer failed to discuss. In particular, he gave little attention to the ways in which governments might facilitate the positive externalities of inward FDI. One example is the promotion of 'industrial districts' and 'clusters; As documented particularly by Porter (1990) agglomerations of inter-linked firms, including MNEs, that compete and cooperate in a particular activity in a particular location, are frequently a potent source of locally-based economic development. They are also an alternative mode of organizing production to 'central planning' that combines much of the efficiency of large and small size, but also exploits and sometimes adds to the social capital of host countries (Dunning, 2005; Pitelis, 2009).

Hymer underplayed all these possibilities. This led him to prescribe central planning to counteract the (perceived) negative effects of value capture by MNEs. This has been prescription was based on the assumption that 'central planning' will maintain the efficiency 
properties of capitalism, while ridding its inefficiencies. But theory suggests that central planning will tend to be inferior in terms of dynamic efficiency through innovations (Hayek 1945).. Over the last three decades central planning has collapsed as an economic system, in most emerging countries. Victorious capitalism, on the other hand is now plagued with one of its worst crises ever, even resorting to its own idiosyncratic form of central planning and rampant protectionism. This invites a more nuanced appreciation of the links between private, public and global and market-hierarchy-co-operation, than currently extant (Mahoney et al 2009).

\section{Learning, Institutions, Sustainability and Concluding Remarks}

The main focus of recent research on the nature and implications FDI and MNE activity has been on evolution, efficiency, learning innovation, and the dynamic interplay between the competitive advantages of firms and countries. Attempts to incorporate firm specific assets and competences into the equation include those of Caves (1982), Teece (2006), and Kogut and Zander (1993) 'evolutionary view'. Increasing attention has been paid to asset augmenting FDI, including that of MNEs from developing countries (UNCTAD 2005). Madhok and Phene (2001) and Rugman and Verbeke (2002) tried to incorporate Penrosean and resource-based ideas into the MNE. Various contributors to Cantwell and Narula (2003) have suggested reconfigurations for extension of the OLI paradigm. More recently, Dunning and Lundan (2008) explicitly incorporated the content and quality of institutional capital into the eclectic paradigm, while Pitelis (2007) reinterpreted and extended its tenets in terms of learning, imperfect cognition and strategic behaviour of firms. While we would accept that many of these ideas were anticipated by Hymer (1970), by choosing to focus on the value capture advantages of the MNE, he neglected an important part of its attributes. In concluding this paper, we speculate as to what a more nuanced, learning, 
knowledge, capabilities, innovations and institutions-based view of the MNE, that combines value capture with value creation, would imply for Hymer's prescriptions and predictions.

First and as already observed, the new emphasis on the learning attributes of FDI and MNE activity supports the 'increasing firm size view' of Hymer. As pointed out by Penrose (1959) this process of growth is efficient, almost by definition. While firms do, and often manage, to capture value resulting from such growth by way of monopolistic practices, and the building of "impregnable bases", sustained growth results from innovation and efficiency. To the extent that "big business competition" fuels that process, it is an important vehicle for value creation.

Concerning “collusion", Penrose (1959) like Hymer (1970) and others were not oblivious to the potential inefficiency of a state or "equilibrium", in sectors controlled by large firms, which might stem the process of competition. Penrose argued however that the emergence of small firms, appropriate anti-trust policies, institutions and attempts by government of developing countries to safeguard their interests, would make it infeasible for large firms to maintain collusion on a global scale for other than short periods of time-in the long term in it innovate of perish (Pitelis, 2004). It would appear that this Penrosean view, currently enforced by much of the new learning on FDI and the MNE, is proving to be more accurate than that of Hymer.

The "new learning" on the MNE and FDI would prescribe the need for new supranational organizations, which focused on sustainable value creation. Such a focus would entail the facilitation of mutual learning, knowledge transfer and the spread of "good practice", standards and institutions to furthering development. They should aim to remove market distorting constraints to development, arising inter alia from inadequate properly right protection, ineffective competition policies and corruption and the strategic trade policies by developed countries that hinder the development process of developing countries (Chang 
2002; Bianchi and Labory 2006). Such a new perspective would suggest a focus on removing the potentially negative effects on sustainable value creation, deriving from some unacceptable value capture practices of firms and nations (Mahoney et al, 2009).

Such an approach would also help explain and facilitate a process of 'uneven development' in favour of catch-up. A learning-sustainable value creation view of firms and nations, would allow for the transfer of best global technological and organizational practices. In addition, the need by MNEs, to access and learn from the competences and institutions in the countries in which they operate might suggest the need for a more decentralized and 'heterarchical' organizational structure aimed to leverage subsidiary skills (Birkinshaw and Hood, 1998). While in some cases, e.g. the contribution of foreign affiliates to the innovatory process, this has happened (UNCTAD, 2005), in others it has not (Pearce and Papanastassiou, 2006; Yamin and Forsgren, 2006)

The above are not meant to assert that convergence necessarily follows as learning and knowledge accumulation increases. Instead learning provides more degrees of freedom for developing countries to pursue strategies that will facilitate development. For a variety of reasons, some developing countries will be successful, others will not (Chang 2002) ${ }^{9}$. However, those that are, may well be eventually able to effect independent and favourable development trajectories. While Hymer's predominant focus on power-related issues and value capture led him to adopt the proposition of uneven and dependent development, our perspective would point to a more nuanced approach to development, but would offer more scope for agency and less predetermined outcomes.

A knowledge- learning based perspective to development would all but be alien to the prescription for central planning. While static efficient allocation of resources through central planning is possible (Lange, 1936), any chances for its success would need to assume an omnipotent, omniscient central planner. Planning, moreover, might blunt the incentives of 
firms to innovate and/or to learn from others. All these remove important sources of efficiency. Yet it is perhaps a paradox that while post-Hymer developments have been very harsh on the central planning thesis-they have not necessarily reduced the role of the state. Indeed in some respects, the state's role in ensuring that there are the right kind and quality of institutions in place to facilitate market transactions is probably as important as it has ever been; and nowhere is this more the case than in the emerging economies (Chang, 2002). The recent financial crisis has confirmed this spectacularly (Stiglitz, 2007).

In recent years the learning perspective has been widened to embrace a more diverse, pluralistic view of capitalism. Such a view acknowledges first the role of a growing number of extra market organizations, including NGOs and special interest groups; second, the widening goals, and/or prioritization of existing goals, development and the ways in which these may be best achieved (Dunning, 2006); third, the recognition by governments from both developed and developing economies of the need to continuously reappraise their policies and institutions in the light of a changing global scenario. Certainly we believe that were he writing today, Hymer would wish to be at the centre of debate on these topics.

In all, Hymer's contribution to the theory and political economy of the FDI and the MNE originated a new field of scholarly endeavours and also predated much of what was to follow. Having said this, Hymer chose to focus on only half of the story, viz the value capture by firms, at the exclusion of efficiency and value creation. Perhaps this was because he believed that the same efficiency properties present would be there, whatever the efforts of firms to capture value. This has proven problematic, not least because it is sometimes that exactly because firms aim to capture value that they need to create value in the first place. Alongside his beliefs that large MNEs were all powerful, that capitalist states in developing nations were weak, that small firms had no chance to compete, and that a socialist state would be able to solve the problems of capitalism, Hymer made some predictions and prescriptions 
that have since proved to be unsupportable. Notable among these were his global collusion thesis, the inevitability of dependent and uneven development, and his prescription of central planning.

While Hymer discussed knowledge and institutions-learning-related issues he chose to do so selectively. Were he writing in the first decade of the 21 st century, we believe he would need to revisit some of his ideas, from a more knowledge-learning-institution-based lens that he himself has earlier helped develop. This would have led him to adopt a more balanced and nuanced outlook to both economic and social development. His constantly evolving thought, from 1960 to the early 1970s, make us confident that this would be the case. Rowthorn (2006), Hymer's co-author of many important works, supports this idea by observing that Hymer was an independent spirit and very much his own man.

In concluding, we have claimed that a knowledge-learning-institution-based perspective, to which Hymer had himself contributed, would point to a more nuanced understanding of the role of large firms in globalisation and capitalistic development. Such a perspective would pay attention to the interactions between value creation and value capture at the evolving nature, functions and organization of both market and non-market institutions (Boddewyn, 2003). A learning perspective would point to the need to adopt organizational forms that facilitate learning and growth by small firms, and by states to adopt policies that aid development. In addition the emphasis of such a perspective on value creation and value capture would point to the need for a focus on relative efficiency of alternative organizations, institutions and systems.

Looking to the future, a learning-value creation perspective would point to the need to address constraints on the sustainability of the value generation process. Such constraints are likely to arise whenever entrenched power structures are reflected in monopolistic practices by firms by strategic trade policies by developed countries, which may work against the 
interests of developing countries (Chang 2002, Pitelis 2009). Unacceptable ethical standards in developed and developing countries, market distortion, collusive relationships of firms, nations, actions by one or other constituents of global capitalism that might degrade the environment, lead to excessive social inequalities or reduce security (Boddewyn and Brewer, 1994; Argitis and Pitelis 2001; Mahoney et al, 2009).

While many of the above were not Hymer's chosen concerns or focus, they are well within his chosen pursuit for a better world. A learning-institution-sustainability perspective adds credence to Hymer's concern and calls for learning and actions to improve our lotHymer's chosen agenda. 


\section{Footnotes}

${ }^{1}$ The 'removal of conflict' idea is in line with Michael Porter's subsequent (1980) analysis of the 'five forces of competition', and is similar in spirit to it. Besides the conventional 'collusion' in international markets, removal of conflict is claimed by Hymer to be achieved through 'interpenetration of investments'. Both Hymer's and Porter's analyses drew heavily on early industrial organisation (IO) analyses of structure/performance (Bain, 1956) that dominated IO circles at the time, and which emphasised barriers to entry, concentration and collusion as crucial determinants to the ability of a firm to capture rents. Subsequent development in IO and the resource-based theory of the firm have questioned this focus; see Mahoney (2005) for a more extensive discussion, and below.

${ }^{2}$ This is a variant of the 'infant industry' argument.

${ }^{3}$ The genealogy is set out and analysed in Dunning (2003).

${ }^{4}$ For the most part, the theory of international trade at the time regarded the firm as a black box. Even Ray Vernon's (1966) product cycle theory of international trade and investment addressed itself to the activities of firms rather than the firm per se. Hymer had already used product life cycle arguments to explain the push towards diversification (in Cohen et al, 1979 and below).

${ }^{5}$ This is even if it is 'asymmetric'. 
${ }^{6}$ Scholars such as Yamin (1991), Cantwell (1991) and Pitelis \& Sugden (1991), have subsequently claimed that the reduction of rivalry idea was an important contribution by Hymer and should have not been discounted.

${ }^{7}$ See Eden (2003) for the historical evolution of the OLI, and Cantwell and Narula (2003), Dunning $(2001,2006)$ for more recent extensions.

${ }^{8}$ As noted, the idea that large firms will try to capture value through both efficiency and power is also a theme of Edith Penrose $(1959,1995)$. Importantly, Hymer's focus on potential collusive behaviour between developed countries states and their MNEs, to further their common interests extends Penrose's views to the political arena. More recently, Boddewyn and Brewer (1994), suggest that political power can be an important means of obtaining market power and competitive advantage. For them "Political behaviour can be a source of efficiency, market power, and legitimacy" (p.1371) The addition of political power to market power helps support Hymer's focus on value capture through the possibility of "imperialism". At the same time Boddewyn and Brewer's focus on efficiency helps expose Hymer's exclusive focus on monopoly.

${ }^{9}$ For a discussion of political economy issues by IB scholars see Brewer (1993), Brewer and Boddewyn (1994). Eden and Lenway (2001), point to the political foundation of 'globalisation' which they consider shaky. 


\section{References}

Argitis, G. and Pitelis, C. 2001. Monetary policy and the distribution of income: Evidence for the United States and the United Kingdom. Journal of Post-Keynesian Economics, vol. 23, no. 4 , pp. $617-638$

Bain, J.S. 1956 Barriers to New Competition: Their Character and Consequences for Manufacturing Industries, Boston, Harvard University Press

Baran, P. and Sweezy, P. 1966. Monopoly Capital, Harmondsworth, Penguin

Bartlett, C. A. and Ghoshal, S. 1989. Managing Across Borders: The Transnational Solution, Boston, Harvard Business School Press

Baumol, W. J. 1991. Perfect Markets and Easy Virtue - Business Ethics and the Invisible Hand, Cambridge, Blackwell

Birkinshaw, J. and Hood, N., eds. 1998. Multinational Corporate Evolution and Subsidiary Development, London, Macmillan

Bianchi, P. and Labory, S. 2006. International Handbook on Industrial Policy, Cheltenham, Edward Elgar

Best, Michael. 1990. The new competition: institutions of industrial restructuring, Cambridge, MA, Harvard University Press. 
Boddewyn, D. J. 2003. Understanding and advancing the concept of 'Nonmarket', Business \& Society, vol. 42 , no. 3 , pp. $297-327$

Boddewyn, D.J. and Brewer L.T. 1994. International-business political behavior: new theoretical directions, Academy of Management Review, vol. 19, pp. 119-143

Buckley, P. J. and Casson, M.C. 1976. The Future of Multinational Enterprise, London, Macmillan

Buckley, P. J. and Casson, M.C. 2007. Edith Penrose's theory of the growth of the firm and the strategic management of multinational enterprises', Management International Review, vol. 47 , no. 2 , pp. $151-174$

Cantwell, J. 1991. Theories of international production', in C. N. Pitelis and R. Sugden, eds. The Nature of the Transnational Firm, London, Routledge

Cantwell, J. and Narula, R., eds. 2003. International Business and the Eclectic Paradigm: Developing the OLI Framework, London and New York, Routledge

Casson, M., ed. 1990. Multinational Corporations, Hants, Edward Elgar

Caves, R. E. 1982. Multinational Enterprise and Economic Analysis, Cambridge, Cambridge University Press 
Chandler, A. D. 1962. Strategy and Structure: Chapters in the History of the Industrial Enterprise, Cambridge, MIT Press

Chandler, A.D. and Redlich, F. 1961. Recent developments in American business administration and their conceptualisation, Business History Review, vol. 35, pp.1-27

Chang, H-J. 1994. The Political Economy of Industrial Policy, London and Basingstoke, Macmillan.

Chang, H-J. 2002. Kicking away the ladder - an unofficial history of capitalism, especially in Britain and the United States, Challenge, vol. 45 , no. 5

Coase, R. H. 1937. The nature of the firm, Economica, vol. 4, pp. 386-405

Cohen, R. B., Felton, N. et al., eds. 1979. The Multinational Corporation: a Radical Approach. Papers by Stephen Herbert Hymer, Cambridge, Cambridge University Press

Cowling, K. and Waterson, M. 1976. Price-cost margins and market structure, Economica, vol. 43 , no. 171 , pp. $267-274$

Driffield, N. L. and Love, J.H. 2005. Intra-industry foreign direct investment, uneven development and globalization, Contributions to Political Economy, vol. 24, no. 1, pp. 55-78

Dunning, J. H. 1958. American Investment in British Manufacturing Industry, London, Allen and Unwin 
Dunning, J. H. 1977. Trade, location of economic activity and the MNE: a search for an eclectic approach, in B. Ohlin, P.O. Hesselborn and P.M. Wijkman, eds. The International Allocation of Economic Activity, London and Basingstoke, Macmillan

Dunning, J. H. 2001. The key literature on IB activities: 1960-2000, in A.C. Rugman and T.L. Brewer, eds. Oxford Handbook of International Business, Oxford, Oxford University Press

Dunning, J. H. 2003. An evolving paradigm of the economic determinants of international business activity', in J. Cheng and M. Hitt, eds. Managing Multinationals in a Knowledge Economy, Oxford, Elsevier, vol.15, pp. 3-27

Dunning, J. H., ed. 2005. Making Globalisation Good: The Moral Challenges of Global Capitalism, Oxford, Oxford University Press

Dunning, J. H. 2006. When I met Hymer: some personal recollections, International Business Review, vol. 15, no. 2, pp. 115-123

Dunning, J. H. 2006. Towards a new paradigm of development: implications for the determinants of international business activity, Transnational Corporations, vol. 15, no. 1, pp. $173-228$

Dunning, J. H. and Lundan, S. M. 2006. The MNE as a creator, fashioner and respondent to institutional change, Mimeo, University of Rutgers and University of Maastricht 
Dunning, J. H. and Pitelis, C. N. 2008. Stephen Hymer's contribution to international business scholarship: an assessment and extension, Journal of International Business Studies, vol. 39 , pp. 167-176.

Dunning, J. H. and Rugman, A. 1985. The influence of Hymer's dissertation of the theory of foreign direct investment, American Economic Review, vol. 75, pp. 228-39

Eden, L. 2003. A Critical Reflection and Some Conclusions on OLI, in John Cantwell and Rajneesh Narula, eds. International Business and the Eclectic Paradigm: Developing the OLI Framework, London and New York, Routledge

Eden, L. and Lenway S. 2001. Multinationals: the Janus face of globalization', Journal of International Business, vol. 32, no. 3, pp. 383-400

Graham, E.M . 1990. Exchange of threat between multinational firms as an infinitely repealed non cooperative game, International Trade Journal, vol. 4, no. 3, pp. 259-277

Hayek, F.A. 1945. The use of knowledge in society, American Economic Review, vol. 35, pp. $519-30$

Hennart, J. F. 1982. A Theory of Multinational Enterprise, University of Michigan Press, Ann Arbor

Hill, C. 2009. International Business, McGraw Hill, $7^{\text {th }}$ Edition 
Hymer, S. H. 1960/1976. The International Operations of National Firms: a Study of Direct Foreign Investment, Cambridge, MIT Press

Hymer, S. H. 1968. The large multinational 'corporation', in M. Casson, ed. 1990. Multinational Corporations, London, Edward Elgar

Hymer, S. H. 1970A. The efficiency (contradictions) of multinational corporations, American Economic Review. Papers and Proceedings, vol. 60, no. 2, pp. 441-448

Hymer, S. H. 1970B. The multinational corporation and the law of uneven development, in J. N. Bhagwati, ed. Economics and World Order, London, Macmillan

Hymer, S. H and Resnick, S. 1969. A model of an agrarian economy with non agricultural activities, The American Economic Review vol. 59, no. 4, pp. 493-506

Hymer, S. and Rowthorn, R. 1970. Multinational corporations and international oligopoly: the non-American challenge, in C. Kindleberger, ed. The International Corporation: A Symposium, Cambridge, MIT Press, pp. 57-91

International Business Review. 2006. Special Issue: Stephen Hymer and International Business Strategy, International Business Review, vol. 15, no. 2, pp. 103-193

Kindleberger, C. P. 1984. Plus ça change - A Look at the New Literature, in Contributions to Political Economy (2002) 21, 5-7 
Kindleberger, C.P., ed. 1984. Multinational Excursions, Cambridge, MIT Press, pp.180-88

Kindleberger, C. P. 2002. Stephen Hymer and the Multinational Corporation, Contributions to Political Economy, vol. 21, pp. 5-7

Kogut, B. and Zander, U. 1993. Knowledge of the Firm and the Evolutionary Theory of the Multinational Corporation, Journal of International Business Studies, vol. 24, no. 4, pp. 625645

Lange, O. 1936. On the Economic Theory of Socialism, The Review of Economic Studies, vol. 4, no. 1 , pp. 53-71

Madhok, A. and Phene, A. 2001. The Co-evolutional Advantage: Strategic Management Theory and Eclectic Paradigm, International Journal of the Economics of Business, vol. 8, no. 2 , pp. $243-256$

Mahoney, J. T. 2005. Economic Foundations of Strategy, London and New York, SAGE Publications

Mahoney, J. T., McGahan, A. and Pitelis C. N. 2009. The Interdependence of Private and Public Interests, Organization Science, forthcoming

Marx, K. 1959. Capital, Vol. 1-3, London, Lawrence and Wishart 
Modigliani, F. 1958. New Developments on the Oligopoly Front, Journal of Political Economy, vol. 66, no. 3, pp. 215-232

Pearce, R. and Papanastassiou, M. 2006. To "Almost See the World": Hierarchy and Strategy in Hymer's View of the Multinational, International Business Review, vol. 15, no. 2, pp. $151-165$

Penrose, E.T. 1959/1995. The Theory of the Growth of the Firm, Oxford, Oxford University Press, $3^{\text {rd }}$ ed.

Pitelis, C. N. 2004. Edith Penrose and the Resource-based View of (International) Business Strategy', International Business Review, vol. 13, no. 4, pp. 523-532

Pitelis, C. N. 2007. Edith Penrose and a Learning-Based Perspective on the MNE and the OLI, Management International Review, vol. 47, no. 2, pp. 207-220

Pitelis, C. N. 2009. The Sustainable Competitive Advantage and Catching-up of Nations: Fdi, Clusters, and the Liability (Asset) of Smallness?, Management International Review, vol. 41 , no. 1

Pitelis, C. N. and Sugden, R., eds. 1991. The Nature of the Transnational Firm, London, Routledge

Pitelis, C.N. and Sugden, R., eds. 2002. Special issue on Stephen Hymer and international political economy, Contributions to Political Economy, vol. 21, no. 1 
Porter, M. E. 1980. Competitive Strategy: Techniques for Analyzing Industries and Competitors, New York, Free Press.

Porter, M.E. 1990. The Competitive Advantage of Nations, New York: Free Press.

Ramamurti, R. 2004. Developing Countries and MNEs: Extending and Enriching the Research Agenda, Journal of International Business Studies, vol. 35, pp. 277-283

Richardson, G. 1972. The Organisation of Industry, Economic Journal, vol. 82, no. 326, pp. 883-896

Rowthorn, R. 2006. Stephen Hymer: An intellectual memoir, International Business Review, vol. 15, pp. 111-114.

Rugman, A. M. 1981. Inside the Multinationals: The Economics of Internal Markets, New York, Columbia University Press.

Rugman, A. M. and Verbeke, A. 2002. Location, competitiveness and the multinational enterprise, in Rugman, A.M. and Brewer, T.L., eds. The Oxford Handbook of International Business, Oxford, Oxford University Press

Sala-i-Martin, X. 2006. The world distribution of income: falling poverty and... convergence, period, The Quarterly Journal of Economics,vol. 121, no. 2, pp. 351-398 
Scherer, F. M. and Ross, D. 1990. Industrial Market Structure and Economic Performance, Boston, Houghton and Mifflin Company

Schumpeter, J. A. 1942. Capitalism, Socialism and Democracy, New York, Harper \& Row

Solow, R. M. 1956. A Contribution to the theory of economic growth, Quarterly Journal of Economics, vol. 70, pp. 65-95.

Stiglitz, J. 2002. Globalization and its Discontents. London, Allen Lane

Stiglitz, J. 2007. Financial hypocrisy, The Economists' Voice, vol. 4, no. 6, pp. 1101-4

Teece, D. J. 1977. Technology transfer by multinational firms: the resource cost of transferring technological know-how, The Economic Journal, vol. 87, pp. 242-261

Teece, D. J. 2006. Reflections on the Hymer thesis and the multinational enterprise, International Business Review, vol. 15, no. 2, pp. 124-139

Vernon, R. 1966. International investment and international trade in the product cycle, The Quarterly Journal of Economics, vol. 80, May 1966, pp. 190-207

Yamin, M. and Forsgren, M. 2006. Hymer's analysis of the multinational organization: power retention and the demise of the federative MNE, International Business Review, vol. 15 , no. 2 , pp. $166-179$. 
UNCTAD. 2003. World Investment Report: Policies for Development: National and

International Perspectives, New York and Geneva, UN

UNCTAD. 2005. World Investment Report: Transnational Corporations and the Internationalization of $R \& D$, New York and Geneva, UN 